Programme Evolution and Change in Community Pharmacy. London, UK: Royal Pharmaceutical Society of Great Britain, 2003.

13 Weinberg M, Murray M, Marero D, Brewer N, Lykens M, Harris $\mathrm{L}$, et al. Issues in conducting randomised controlled trials of health services research interventions in non-academic practice settings: the case of retail pharmacies. Health Serv Res 2002; 37: 1067-1077.

14 Gardner JS, Hutchings J, Fuller TS, Downing D. Increasing access to emergency contraception through community pharmacies: lessons from Washington state. Fam Plann Perspect 2001; 33: 172-175.

15 Wells ES, Hutchings J, Gardner JS, Winkler JL, Fuller TS, Downing $\mathrm{D}$, et al. Using pharmacies in Washington State to expand access to emergency contraception. Fam Plann Perspect 1998; 30: 288-290.

16 Sommers SD, Chaiyakunapruk N, Gardner JS, Winkler J. The emergency contraception collaborative prescribing experience in Washington State. J Am Pharm Assoc 2001; 41: 60-66.

17 Sucato GS, Gardner JS, Koepsell TD. Adolescents' use of emergency contraception provided by Washington State pharmacists. J Pediatr Adolesc Gynecol 2001; 14: 163-169.

18 Seston E, Hassell K, Cantrill J, Nicolson M, Noyce P, Schafheutle E. Experiences of establishing and maintaining a community pharmacy research network. Primary Health Care Res Develop 2006; 4: 245-255.

19 Adamcik BA, Ransford HE, Oppenheimer PR, Brown JF, Eagan PA, Weissman FG. New clinical roles for pharmacists: a study of role expansion. Soc Sci Med 1986; 23: 1187-1200.

20 Gilbert H, Mills E, Ward E. How can community pharmacists become involved in practice research? Pharmaceutical Journal 2006; 276(7385): 104

21 Pharmacy Practice Research Trust. Evaluation of the Implementation of the Community Pharmacy Contractual Framework in England and Wales. Q\&As on Community Pharmacy Contractual Framework Briefing Paper. London, UK: Pharmacy Practice Research Trust, 2007.

22 Guest D, Oakley P, Budjanovcanin A. Pharmacy Academics Workforce Strategy. Executive Report. Key Findings and Policy Options. London, UK: King's College London, 2007.

\title{
FACULTY OF SEXUAL \& REPRODUCTIVE HEALTHCARE AWARDS
}

The Faculty of Sexual and Reproductive Healthcare has available a number of annual awards for which applications are invited from Faculty members and non-members. Details of the individual awards, together with an application form and/or guidelines on how to apply and any eligibility criteria, may be found on the Faculty website at www.fsrh.org.

\section{Margaret Jackson Prize Essay}

The Faculty will award three prizes annually in memory of Dr Margaret Jackson, a distinguished pioneer in the field of family planning. These prizes are awarded to undergraduates who write the three best essays on a topic related to reproductive health care or fertility control. The first prize is $£ 300$, with $£ 100$ each for the two runners-up. Entries should not exceed 3000 words.

Eligibility: Individuals (undergraduate medical students)

Closing date: 24 March annually

The David Bromham Annual Memorial Award

David Bromham was the first Chairman of the Faculty of Family Planning and Reproductive Health Care (as the Faculty was then known). Sadly, halfway through his second term of office he became ill, and in 1996 he died. His loss was tragic, not only for the Faculty, but for the family planning movement in Britain and worldwide. Whilst in Leeds he set up an assisted conception programme, which was and is one of the most successful in the world. In 1991 he set up a fertility control unit designed to provide a more accessible service for the termination of pregnancy. He also carried out an extensive programme of research and was closely involved with the British Journal of Family Planning (now the Journal of Family Planning and Reproductive Health Care).

The Award is not intended to be a prize for a long and distinguished service, rather for a piece of work which through inspiration, innovation or energy has furthered the practice of family planning and reproductive health care in any way and any setting. It is not a research grant. Younger health professionals sometimes undervalue their achievements but they are exactly the people that David Bromham would have wished to see encouraged as this award now acknowledges.

The award will be made either to an individual (who must be a current Diplomate, Member or Fellow of the Faculty) or to a team, which could be multidisciplinary. In the latter case, the lead doctor should be a current member of the Faculty. You may nominate yourself or your team or be nominated by someone else.

Eligibility: Individuals (Faculty members) or teams Closing date: 7 April annually

International Travelling Scholarship of the Faculty

The Faculty offers a scholarship for those Faculty members who are interested in going abroad to visit international colleagues, services, research or educational establishments in order to learn about some aspect of family planning or reproductive health care. The award will be for a maximum of $£ 2000$. The recipient of the award will be required to give a presentation at a Faculty conference.

Eligibility: Individuals (Faculty members) Closing date: 7 April annually

The 4-0-8 Sheffield Fund

In 2001, the 4-0-8 Young People's Consultation Centre Ltd, Sheffield made a significant donation to the Faculty for the purpose of funding training for health care professionals who have limited funding for attending training meetings. Any person working in the field of reproductive and sexual health care within the UK may apply. Approximately $£ 4000$ is allocated annually, divided between the successful applicants.

Eligibility: Individuals (Faculty members/non-members)

Closing date: See website for details 